\title{
COPING STRATEGIES OF THE FARM LABORERS TOWARD FARM MECHANIZATION IN CENTRAL, SAN JOSE, OCCIDENTAL MINDORO
}

\author{
Mary Yole Apple Declaro-Ruedas*, Leoniel S. Bais \\ Occidental Mindoro State College, San Jose, Occidental Mindoro, Philippines. \\ *Corresponding author e-mail: tsinelas_yole@yahoo.com
}

Citation: Declaro-Ruedas, M.Y.A., and Bais, L.S. 2020. Coping strategies of the farm laborers toward farm mechanization in Central, San Jose, Occidental Mindoro. J. Asian Rur. Stud. 4(1): $109-118$

\begin{abstract}
This descriptive study was conducted to determine the coping strategies of farm laborers in San Jose, Occidental Mindoro towards farm mechanization. It was conducted at Barangay Central, San Jose, Occidental Mindoro, one of the top rice producing barangays in the province. The 123 of the 215 farm laborers listed in the different Kabesilya or farmers labor group were selected using simple random sampling. The farm laborers were engaged in planting and harvesting of rice for at least three years in Central, San Jose, Occidental Mindoro. The researcher used an interview schedule in gathering data. The study used descriptive statistics such as mean, frequency, and percentage. Pearson's Product Moment Correlation was also used. Result shows that the farm laborers were in their middle aged, literate and with medium household size. The farm laborers generally "agree" that farm mechanization had affected their employment, food security level, education of children, monthly income, and agricultural production operations. The farm laborers "moderately practiced" the different coping strategies to meet the undesired effect of farm mechanization. Further, the "highly practiced" coping strategies were minimizing food expenses and seasonal migration of some household members to find odd jobs. Moreover, years spent in formal education and household size has a significant relationship on the extent of which farm laborers experience the effect of farm mechanization. Years spent in formal education have significant relationship on the coping strategies employed by farm laborers on advent of farm mechanization in the area.
\end{abstract}

Keywords: Coping strategy, Farm laborers, Mechanization, Kabesilya

\section{Introduction}

Farm mechanization is the use of machines and technology in the agriculture sector. The use of tractor, tube-wells and plant protection measures are included in the mechanization. So in the farm mechanization the use of machinery is greater as compared to the labor hence, has decreasing need for man power (Alojado Publishing International, 2015).

The greatest impact of mechanization has been an enormous increase in productivity per farm worker - overall production and production per hectare has grown considerably, but the total number of hours worked has fallen. There has been a large 
drop in the number of farmers and farm workers, and less work is now done by farmers' families. The long-term pattern has been to replace expenditure on labor with investment in machinery.

Javier (2015) said that mechanization in agriculture largely takes place against the background of broad-based economic growth; socio-demographic changes in flows of labor, and policies that result in foreign investment and transfer of technology and management know-how into the manufacturing sector, and not something singularly pursued as a policy objective absent other pre-conditions.

Occidental Mindoro is an agricultural area devoted primarily for rice production, which is the sole leading activity and source of seasonal employment for farm laborers including children in the province. Moreover, due to the increase of output in rice production by $1.41 \%$ from January to March 2015 as reported by the Philippine Statistics Authority (2015), it indicates that the positive growth because of expanded areas for harvesting of rice brought an increase to farmers' intension to plant rice for production which in return results to greater number of employment for farm laborers. Impliedly, the more are needed, the greater the cost of production that is why some farm owners chose to use mechanize farming system to reduced labor cost.

Rice farming therefore demands the primary contribution of labor in farming communities and is necessary to have knowledge and understanding on effect of technological advancement to employment for rice production as key identity towards family income utilization for survival. On the other hand, farm workers in developing countries like the Philippines are declining because of the introduction of farm mechanization. Farm mechanization refers to the use of machineries and technologies in farming system to ease the work and minimize farm expenses and is considered to provide optimum return of investment to farm owners due to the reduction of labor costs. Farm mechanization is one of the reasons why hired labor are reduced instead due to the costs that represents around $60 \%$ of the total input in rice production and therefore have to minimize in order for the farm owners to lessen the cost and dependence to the unreliable supply of hired labour (Alojado Publishing International, 2015).

Though mechanize farming system greatly increase farm owner's income, food security, and quality of life, still, it rooted to a major problem in the society and that is the increasing level of unemployment for farm workers in the country. Rahman, Miah and Hossain (2003) concludes that mechanization has adverse effects on family labor and more research need to be conducted to develop appropriate technology to increase 
the production of wheat without substituting labor. Sison (2000) pointed out in his study the effect of mechanize farming practice in Nueva Ecija that greatly reduced the hired labor resulting to unemployment.

This study was conducted to determine the coping strategies of farm laborers in San Jose, Occidental Mindoro towards farm mechanization. Specifically, it aims to (1) determine the profile of the farm laborers, (2) determine the extent to which farm laborers experience the effects of farm mechanization, (3) determine the coping strategies employed by farm laborers towards farm mechanization, (4) determine the significant relationship between the farm laborers' profile and the extent to which they experience the effects of farm mechanization practices, and (5) determine the significant relationship between the farm laborers' profile and the coping strategies employed by farm laborers towards the effects of farm mechanization practices.

\section{Conceptual Framework}

The relationship between dependent and independent variables are shown in the conceptual framework. Independent variable which contains the farm laborers'profile as to age, number of years spent in formal education, and household size. There are dependent variables which are the farm laborers' coping strategies towards the effect of farm mechanization and the extent to which farm laborers experience the effects of farm mechanization. The content of the first box and the second box up to the third box were connected with a line in which the arrow is pointing the second.

Independent Variable

\footnotetext{
Farm Laborer Profile

a. age;

b. years spent in formal education; and

c. household size.

Effects of farm mechanization

d. employment;

e. food security level

f. education of children; and

g. monthly income.
} 


\section{Methodology}

This study was conducted at Barangay Central, San Jose, Occidental Mindoro, one of the top rice producing barangays in the province. The study was conducted using the descriptive research design. Descriptive research was used to obtain information concerning the current status of the phenomena to describe what exists with respect to variables and conditions in a situation.

The 123 of the 215 farm laborers listed in the different Kabesilya or farmers labor group were selected using simple random sampling. The farm laborers were engaged in planting and harvesting of rice for at least three years in Central, San Jose, Occidental Mindoro.

The researcher used an interview schedule in gathering data. It was validated and translated to Filipino to make it understandable to farm laborers. The study used descriptive statistics such as mean, frequency, and percentage. Pearson's Product Moment Correlation was also used.

\section{Results and Discussion}

\subsection{Profile of farm laborers in Barangay Central, San Jose, Occidental Mindoro}

Table 1 presents the profile of the farm laborers, which includes age, number of years spent in formal education, and household size.

Age is also an important personal characteristic in farming. The average age of Filipino farmers is 57, or more than doubles the national average of 23. The Philippines is one of few Asian countries reaping the so-called demographic dividend, as it is beginning to see a bigger segment of the population join the labor force (Despuez,2014). In the study, the mean age of the farm laborers were 40.10 years old with a standard deviation of 0.07 . This implies that they are in their middle age and can still perform the needed labor requirement in rice farming. However, Ours (2010) posits that labor productivity could decline between 40-50 years old.

The farm laborers were functional literate with a mean number of years spent in formal school of 5.58 years ranging from 4-10 years. The standard deviation is 0.08 , which implies that they have homogenous educational level. They were educated only up to some elementary school levels with many forced to work in the farm early in their lives because of poverty.

The findings corroborates with the study of Rivera et al. (2001) that most farmers in the developing world have a low level of formal education and extremely few have the opportunity to study agriculture in the formal school system. Further, Nicolas (2015) 
also describes 'kabesilya' labourers in San Jose, Occidental Mindoro with low level of formal education. The farm laborers have medium household size with a mean of 5.49 ranging from 3-10 family members. This shows that the increasing number of family members would undesirably disturbs the capacity of the family heads to offer the basic necessities of life i.e. food, medicine, education and clothing.

Table 1. Profile of rice farm laborers in Barangay Central, San Jose, Occidental Mindoro.

\begin{tabular}{lccc}
\hline \multicolumn{1}{c}{ Profile } & Mean & Range & Standard Deviation \\
\hline Age & 40.10 & 29-60 years old & 0.07 \\
$\begin{array}{l}\text { Number of years spent in formal } \\
\text { education }\end{array}$ & 5.58 & 4-10 years & 0.08 \\
Household size & 5.49 & $3-10$ & 0.03 \\
\hline
\end{tabular}

\subsection{Extent to which farm laborers experience the effect of farm mechanization}

The farm laborers experience on the extent of farm mechanization is reflected in Table 2. They "strongly agree" that due to farm mechanization there is limited employment during rice transplanting season ( $\mathrm{WM}=4.84$ ), seasonal migration of farm family members to look for jobs ( $\mathrm{WM}=4.83)$, limited participation during harvesting season (WM=4.76), educational attainment of the farm laborers household is also affected (WM=4.73), and the utilization of children in rice farming activities (WM=4.65). On the other hand, they also "agree" that wages is being reduce for the available jobs in farming operations $(\mathrm{WM}=4.28)$. There is also insufficient salary gained every month that is used in daily expenses on the cost of living ( $\mathrm{WM}=3.92)$, and the incapacity of the parents to send their children in school (WM=3.62).

Table 2. Extent to which farm laborers experience the effect of farm mechanization.

\begin{tabular}{lcc}
\hline \multicolumn{1}{c}{ Particulars } & $\begin{array}{c}\text { Weighted } \\
\text { Mean }\end{array}$ & Interpretation \\
\hline $\begin{array}{l}\text { 1. Farm laborers' employment is reduced due to the } \\
\text { introduction of farm mechanization. }\end{array}$ & 4.84 & Strongly agree \\
$\begin{array}{l}\text { 2. Family's budget for food, clothing and medicine are } \\
\text { negatively affected by farm mechanization }\end{array}$ & 4.26 & $\begin{array}{c}\text { Agree } \\
\text { Agree }\end{array}$ \\
$\begin{array}{l}\text { 3. Incapacity of the parents to send their children in school } \\
\begin{array}{l}\text { 4. Insufficient salary gained every month that is used in } \\
\text { daily expenses on the cost of living }\end{array} \\
\begin{array}{l}\text { 5. Limited participation by farm laborers during low land } \\
\text { irrigated and non-irrigated rice transplanting seasons }\end{array}\end{array}$ Agree \\
$\begin{array}{l}\text { 6. Limited participation by farm laborer during low land } \\
\text { irrigated and non-irrigated rice manual harvesting seasons }\end{array}$ & 4.84 & Strongly agree \\
$\begin{array}{l}\text { 7. Limited participation by farm laborers during post-harvest } \\
\text { operations like threshing and rice grain drying }\end{array}$ & 4.76 & Strongly agree \\
\end{tabular}


8. Other occupational source is greatly affected by educational attainment of the farm laborers household

\subsection{Strongly Agree}

9. Increasing tendency for the farm families to move and look for jobs in other places

10. Increasing child labor in rice farming activities

$4.83 \quad$ Strongly Agree

4.65 Strongly Agree

Agree

11. Reduced wage for the available jobs in farming operations

Over all mean

4.28

4.42

Agree

Legend: $0.50-1.50=$ Strongly disagree; $1.51-2.50=$ Disagree; $2.51-3.50=$ Moderately agree; $3.51-4.50=$ Agree; and 4.51-5.50= Strongly agree

\subsection{Coping strategies employed by farm laborers towards farm mechanization}

It is well known that poor households in developing countries, particularly in rural areas, adopt various ex ante as well as ex post strategies in the variable environment (Dercon, 2005). Those strategies include ex ante crop and income diversification, ex post off-farm economic activities including temporary migration, assets typically livestock sales, and receiving gifts and remittances. It can be deduced that farm laborers "highly practiced" the cutting down on food consumption and other essentials to cope up with the impact of farm mechanization $(\mathrm{WM}=4.76)$ and the seasonal migration of parents to other areas to find job $(\mathrm{WM}=4.65)$.

They "moderately practiced" forcing children to participate on livelihood activities and farming operations like transplanting rice seedlings, harvesting and drying of grains $(\mathrm{WM}=3.72)$.

Table 3. Coping strategies employed by farm laborers towards farm mechanization.

\begin{tabular}{|c|c|c|}
\hline Particulars & $\begin{array}{l}\text { Weighted } \\
\text { Mean }\end{array}$ & Interpretation \\
\hline $\begin{array}{l}\text { 1. Involvement in livelihood activities like basket making, } \\
\text { weaving, and other types of crafts that can be produced at } \\
\text { home and in off-season and other employment activities }\end{array}$ & 1.95 & Less Practiced \\
\hline $\begin{array}{l}\text { 2. Dependence to village support system by providing } \\
\text { credit or a little land to grow vegetables }\end{array}$ & 2.81 & Practiced \\
\hline 3. Cutting down on food consumption and other essentials & 4.76 & Highly Practiced \\
\hline 4. Seasonal migration of parents to other areas to find job & 4.65 & Highly Practiced \\
\hline $\begin{array}{l}\text { 5. Children are sent to parent's family for proper care and } \\
\text { attention while the parents themselves can't afford to give } \\
\text { the children's primary needs }\end{array}$ & 2.76 & Practiced \\
\hline $\begin{array}{l}\text { 6. Dependence to government and non- } \\
\text { government support system for financial, } \\
\text { educational and health assistance }\end{array}$ & 2.36 & Less Practiced \\
\hline $\begin{array}{l}\text { 7. Selling/trading of either large or small portions of } \\
\text { properties like small lot,rice stock, appliances, etc. } \\
\text { 8. Children are forced to participate on livelihood activities } \\
\text { and farming operations like transplanting rice seedlings, }\end{array}$ & 1.95 & $\begin{array}{l}\text { Less Practiced } \\
\text { Moderately } \\
\text { Practiced }\end{array}$ \\
\hline
\end{tabular}


harvesting and drying of grains

9. Farm laborers are shifting to small farm lands where

farm holders are unable to purchase machines and use of such is not profitable

10. Membership to cooperatives in order to received

Practiced

benefits like micro lending.

Over all mean

Practiced

Legend: $0.50-1.50=$ Not practiced; $1.51-2.50=$ Less
$4.50=$ Practiced; and $4.51-5.50=$ Highly practiced

Moreover, they also "practiced" dependence to village support system by providing credit or a little land to grow vegetables $(\mathrm{WM}=2.81)$, sending children to the parent's family for proper care and attention while the parents themselves can't afford to give the children's primary needs (WM=2.76), membership to cooperatives in order to received benefits like micro lending $(\mathrm{WM}=2.56)$, dependence to government and non-government support system for financial, educational and health assistance like the 4Ps (WM=2.36).

Meanwhile, they "less practiced" the involvement in livelihood activities like basket making, sewing, weaving and other types of crafts that can be produced at home and in off-season and other employment activities (WM=1.95) as well as selling/trading of their large or small portions of properties like small lot, rice stock, appliances, etc. $(\mathrm{WM}=1.95)$.

\subsection{Relationship of farm labourers' profile and extent of effect of farm mechanization}

The number of years spent in education has "slight relationship" on the extent of effects of farm mechanization thus null hypothesis is rejected. It recorded a computed $r$ value of 0.28 which is higher than the tabular $r$ value of 0.18 . However, age and household size has "negligible relationship," which registered a computed r value lower than the tabular $r$ value. Thus, the null hypothesis is rejected.

Table 4. Test of relationship of farm laborers' profile and extent of effect of farm mechanization.

\begin{tabular}{lccl}
\hline \multicolumn{1}{c}{ Profile } & r com. & r crit. & \multicolumn{1}{c}{ Interpretation } \\
\hline Age & -0.02 & 0.18 & $\begin{array}{l}\text { Negligible relationship, } \\
\text { Not significant } \\
\text { Slight relationship } \\
\text { Years spent in formal education }\end{array}$ \\
Household size & -0.28 & 0.18 & $\begin{array}{l}\text { Significant } \\
\text { Negligible relationship, } \\
\text { Not significant }\end{array}$ \\
\hline
\end{tabular}




\subsection{Relationship between farm labourers' profile and coping strategies employed}

Number of years spent in formal education has a "slight relationship" on the coping strategies employed by farm laborers on the effect of farm mechanization. This is supported by the registered computed $r$ value of 0.32 , which is lower than the tabular $r$ value of 0.18 . Thus, the null hypothesis is rejected.

However, age and household size has a "negligible relationship" with the coping mechanisms employed.

Table 5. Relationship between farm laborers' profile and coping strategies employed.

by farm labourers towards farm mechanization

\begin{tabular}{|l|c|c|l|}
\hline \multicolumn{1}{|c|}{ Profile } & r com. & r crit. & \multicolumn{1}{|c|}{ Interpretation } \\
\hline Age & 0.04 & 0.18 & $\begin{array}{l}\text { Negligible Relationship, } \\
\text { Not Significant }\end{array}$ \\
\hline Years spent in formal education & -0.32 & 0.18 & $\begin{array}{l}\text { Slight Relationship, } \\
\text { Significant }\end{array}$ \\
\hline Household size & -0.01 & 0.18 & $\begin{array}{l}\text { Negligible Relationship, } \\
\text { Not Significant }\end{array}$ \\
\hline
\end{tabular}

\section{Conclusions}

This study has the following conclusions:

1. The farm laborers were in their middle aged, literate and with medium household size.

2. The farm laborers generally "agree" that farm mechanization had affected their employment, food security level, education of children, monthly income, and agricultural production operations.

3. The farm laborers "moderately practiced" the different coping strategies to meet the undesired effect of farm mechanization. Further, the "highly practiced" coping strategies were minimizing food expenses and seasonal migration of some household members to find odd jobs.

4. Years spent in formal education and household size has a significant relationship on the extent of which farm laborers experience the effect of farm mechanization.

5. Years spent in formal education have significant relationship on the coping strategies employed by farm laborers on advent of farm mechanization in the area. 
In the light of forgoing findings, the researcher would like to forward the following recommendations:

1. Include the farm laborers' monthly or annual income in order to comprehensively analyze the significant effect of economic status with that of the extent effect and coping strategies employed on the effect of farm mechanization.

2. Conduct extension programs and livelihood assistance that will equip the farm laborers with knowledge and skills for alternative sources of income.

\section{References}

Agricultural Machinery Information Network. (2006).Bureau of Statistics National Survey. Philippines. Retrieved July 20, 2015, from http//:www.philippineislands.ph.

Alojado Publishing International. (2015).Occidental Mindoro. Philippines, People \& Country, Culture, History, Everyday Life \&Tourism, Music, \&Gallery. Retrieved July 20, 2015, from http//:www.mindoro -islands.ph.

Barker E. @ Cordova, R. (2007). “Landless \& Hired Labour in Philippines Rice Farm”. The University of Michigan, Center for Development Studies. Retrieved July 20, 2015, from http//:www.development studies for U.S.ph.

Carner, G. (2000), Independence \& Competition among the Philippine Rural Poor. Manila Bulletin News. Manila, Philippines. Retrieved July 22, 2015 from mb.com.ph | Philippines.

Emerson, R. (2003). Farm Mechanization \& the farm Labor Market: A Socioeconomic Model of induced Innovation. International Agriculture Trade \& Policy Center, Food \& Resource Department. University of Florida, America.

INSInet Publication, (2010). Impacts of rice combined Harvesters on Economy \& Social Status of Farmers in the village of Tung Kula Ronghai Region, Thailand. Research journal of Agriculture and Biological Sciences, 6(6): 778-784.

Javier, E. (2015). Mechanization of Rice Farming. Manila Bulletin News. Manila, Philippines. Retrieved July 22, 2015, from mb.com.ph | Philippines.

Philippine Statistics Authority, (2015).Rice and Corn Situation Outlook. Manila, Philippines: Department of Agriculture \& Bureau of Plant Industry (BPI). Retrieved July 23, 2015 from www. philippinestatisticsauthority.ph.

Rahman, M.S., Miah, M. A. \& Hossain, S. (2003). Impact of farm mechanization on labor Use for Wheat Cultivation in Northern Bangladesh. Agricultural 
Economics Division, Bangladesh Agricultural Research Institute, Gazipur. Bangladesh.

Sison, J. f., Herdt, R. W. \& Duff, B. (2000). The Effects of Farm Mechanization on Employment Output in Selected Rice Growing Areas in Nueva Ecija, Philippines. Development Academy of the Philippines. Laguna, Philippines

Sison, J. (2000). Farm Mechanization Update. United Kingdom News. Retrieved July 22, 2015 from mb.com.ph/UK News.

Takahashi, A.J. (2005). Landless Workers \& Rice Farming. Los Baños, Laguna: International Rice Research Institute.

USDA. (2012). The National Agricultural Workers Survey, Employment. Retrieved February 16, 2016, from www.doleta.gov/agworker/news.cfm. 